\section{The conversion of $\mathrm{H}_{2} \mathrm{~S}$ to sulfane sulfur: authors' response}

\author{
Bindu D. Paul and Solomon H. Snyder
}

Recently we reviewed $\left(\mathrm{H}_{2} \mathrm{~S}\right.$ signalling through protein sulfhydration and beyond. Nature Rev. Mol. Cell Biol. 13, 499-507 (2012)) ${ }^{1}$ accumulating evidence that hydrogen sulfide $\left(\mathrm{H}_{2} \mathrm{~S}\right)$ is an important biological messenger molecule that signals by forming persulfide (SSH) bonds on Cys residues of target proteins, transforming their sulfhydryl group (SH) to an $\mathrm{SSH}$ group, a process referred to by ourselves and others as 'sulfhydration' ${ }^{1-5}$. In a correspondence article (Nature Rev. Mol. Cell Biol. 15 Nov 2012 (doi:10.1038/nrm3391c1)), Toohey ${ }^{6}$ suggests that sulfhydration may be a misleading designation because the term 'hydration' typically involves the addition of water. We coined the term sulfhydration because the process involves $\mathrm{SH}$ groups. This designation has now been used widely in the literature and is generally accepted, so that there is little ambiguity. The author also suggests that the implied reaction for protein sulfhydration (protein- $\mathrm{SH}+\mathrm{H}_{2} \mathrm{~S} \rightarrow$ protein-SSH) is not a balanced chemical equation. We agree that the reaction diagram

\begin{tabular}{|c|c|}
\hline \multicolumn{2}{|l|}{$\begin{array}{l}\text { Table } 1 \text { | Selected targets of } \\
\text { sulfhydration }\end{array}$} \\
\hline Protein modified & Ref \\
\hline GAPDH & 2 \\
\hline$\beta$-actin & 2 \\
\hline$\beta$-tubulin & 2 \\
\hline PTP1B & 3 \\
\hline Kir6.1 subunit of $K_{\text {ATP }}$ & 7 \\
\hline $\mathrm{IK}_{\mathrm{Ca}}$ & 7 \\
\hline p65 subunit of NF-kB & 5 \\
\hline Parkin & $\begin{array}{l}\text { Unpublished } \\
\text { observations }\end{array}$ \\
\hline Riftia pachyptila haemoglobin & 8 \\
\hline $\mathrm{Cu} / \mathrm{ZnSOD}$ & 9 \\
\hline $\begin{array}{l}\text { GAPDH, glyceraldehyde-3-phosph } \\
\text { dehydrogenase; IK } \text {,a, intermediate } \\
\text { calcium-activated potassium chan } \\
\text { ATP-sensitive potassium channels; } \\
\text { inwardly rectifying potassium chan } \\
\text { NF-kB, nuclear factor-kB; PTP1B, p } \\
\text { Tyr phosphatase } 1 \mathrm{~B} \text {; SOD, superox }\end{array}$ & $\begin{array}{l}\text { ate } \\
\text { conductance } \\
\text { nel; } \mathrm{K}_{\text {ATP }} \\
\text { Kir6.1, } \\
\text { nel 6.1; } \\
\text { otein } \\
\text { de dismutase. }\end{array}$ \\
\hline
\end{tabular}

presented in the correspondence is not chemically balanced. Our Review did not address chemical mechanisms. We focused instead on physiological implications of sulfhydration.

Because both $\mathrm{H}_{2} \mathrm{~S}$ and Cys-SH groups in most proteins are chemically reactive, one would expect $\mathrm{H}_{2} \mathrm{~S}$ donors to sulfhydrate proteins. The important question is whether this phenomenon occurs physiologically. Development of the modified biotin-switch technique $^{2}$ and, subsequently, the maleimide procedure $^{5}$ provided direct evidence that sulfhydration of numerous proteins occurs under basal conditions. Sulfhydration of proteins seems to be more prevalent than nitrosylation. The process was shown to be physiologically relevant in studies using mice that have a targeted deletion of the $\mathrm{H}_{2} \mathrm{~S}$ biosynthetic enzyme cystathionine $\gamma$-lyase (CSE; also known as $\gamma$-cystathionase $)^{2,5}$. Even since the publication of our Review article, the list of proteins that are physiologically sulfhydrated has grown substantially (TABLE 1). Different classes of proteins are sulfhydrated, including numerous enzymes, ion channels and drug or neurotransmitter receptors. These modifications affect disease processes and physiology. For instance, parkin is an E3 ubiquitin ligase that, when mutated and inactive, contributes to autosomal recessive Parkinson's disease. Sulfhydration of parkin markedly increases its catalytic activity (M. S. Vandiver and S.H.S., unpublished observations), which is neuroprotective. In patients with Parkinson's disease, parkin sulfhydration is markedly reduced, leading to diminished catalytic activity. Pathophysiological relevance is implied by the reversal of Parkinson's disease neurotoxicity by treatment with $\mathrm{H}_{2} \mathrm{~S}$ donors.

Sulfhydration contrasts with nitrosylation in terms of effects on catalytic activity of the enzymes. Nitrosylation 'caps' reactive Cys residues and so is typically associated with inhibition of catalytic activity. By contrast, sulfhydration conserves and sometimes enhances sulfhydryl reactivity, often stimulating the catalytic activity of enzymes. One notable exception comes from the elegant study of Tonks and collaborators ${ }^{3}$, who showed that physiological sulfhydration of the phosphatase PTP1B inhibits the catalytic activity of the enzyme, thereby enhancing the cytoprotective response to endoplasmic reticulum stress. By contrast, the inwardly rectifying potassium channel subunit Kir6.1 and the intermediate conductance calcium-activated potassium channel $\mathrm{IK}_{\mathrm{Ca}}$ are activated by sulfhydration ${ }^{7}$.

The field of $\mathrm{H}_{2} \mathrm{~S}$ biology and signalling by protein sulfhydration is young. However, it is already apparent that under basal conditions most proteins are sulfhydrated, with notable impact on their function. For instance, in CSE-knockout mice, the loss of glyceraldehyde-3-phosphate dehydrogenase (GAPDH) sulfhydration is associated with a 25-30\% decrease in hepatic GAPDH catalytic activity, with no change in total GAPDH protein levels ${ }^{2}$. Accumulating evidence suggests that sulfhydration may emerge as a post-translational modification comparable in importance to phosphorylation.

Bindu D. Paul and Solomon H. Snyder are at The Solomon H. Snyder Department of Neuroscience, Johns Hopkins University School of Medicine, Baltimore, Maryland 21205, USA.

Solomon H. Snyder is also at the Departments of Pharmacology and Psychiatry, Johns Hopkins University School of Medicine, Baltimore, Maryland 21205, USA.

Correspondence to S.H.S e-mail: ssnyder@jhmi.edu doi: 10.1038/nrm3391-c2

1. Paul, B. D. \& Snyder, S. H. $\mathrm{H}_{2} \mathrm{~S}$ signalling through protein sulfhydration and beyond. Nature Rev. Mol. Cell Biol. 13, 499-507 (2012).

2. Mustafa, A. K. et al. $\mathrm{H}_{2} \mathrm{~S}$ signals through protein S-sulfhydration. Sci. Signal 2, ra72 (2009).

3. Krishnan, N., Fu, C., Pappin, D. J. \& Tonks, N. K. $\mathrm{H}_{2} \mathrm{~S}$-induced sulfhydration of the phosphatase PTP1B and its role in the endoplasmic reticulum stress response. Sci. Signal 4, ra86 (2011).

4. Nishida, M. et al. Hydrogen sulfide anion regulates redox signaling via electrophile sulfhydration. Nature Chem. Biol. 8, 714-724 (2012).

5. Sen, N. et al. Hydrogen sulfide-linked sulfhydration of NF-KB mediates its antiapoptotic actions. Mol. Cell 45, 13-24 (2012).

6. Toohey, J. I. The conversion of $\mathrm{H}_{2} \mathrm{~S}$ to sulfane sulfur. Nature Rev. Mol. Cell Biol 15 Nov 2012 (doi:10.1038/nrm3391-c1).

7. Mustafa, A. K. et al. Hydrogen sulfide as endothelium derived hyperpolarizing factor sulfhydrates potassium channels. Circ. Res. 109, 1259-1268 (2011).

8. Zal, F. et al. S-sulfohemoglobin and disulfide exchange: the mechanisms of sulfide binding by Riftia pachyptila hemoglobins. Proc. Natl Acad. Sci. USA 95, 8997-9002 (1998).

9. de Beus, M. D., Chung, J. \& Colon, W. Modification of cysteine 111 in $\mathrm{Cu} / \mathrm{Zn}$ superoxide dismutase results in altered spectroscopic and biophysical properties. Protein Sci. 13, 1347-1355 (2004).

Competing interests statement

The authors declare no competing financial interests. 